Јована Касаш

Универзитет у Новом Саду

Филозофски факултет

Одсек за историју

majovanakasas@yahoo.com
Оригиналан научни рад

примљено: 27. март 2013

прихваћено: 1. октобар 2013

\title{
ПРИЛИКЕ У ТЕМИШВАРУ КРАЈЕМ 1918. ГОДИНЕ И ЈЕДАН НЕПОЗНАТИ ДОКУМЕНТ ТЕМИШВАРСКИХ СРБА
}

Сажетак: У раду се доносе сложени актуелни национални проблеми и говори о жељи темишварских Срба да живе у југословенској држави. Научној јавности презентујемо и до сада непознати Записник седнице Српског народног одбора у Темишвару 13/26. децембра 1918. године.

Кључне речи: Темишвар, Српско народно веће, Српска народна управа (Народна управа за Банат, Бачку и Барању), 1918. година.

Народна већа су оснивана на територији Аустро-Угарске током новембра последње ратне године са циљем да се убрза ослобођење и уједињење. ${ }^{1}$ У Темишвару је 31. октобра 1918. године формирано Српско народно веће. Српско народно веће у Темишвару било је први орган власти српског народа на територији Угарске. ${ }^{2}$ Темишвар је био привредни и политички центар Баната. ${ }^{3}$ Колико је овај град за Србе био значајан у историји најбоље показује то што је био изабран да се у

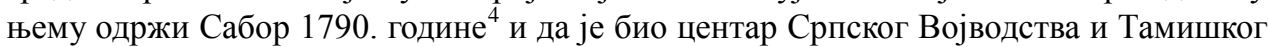
Баната (1849-1860. године).

Банат је први био на удару источне Антантине и српске вјске. Да би га сачували, мађарски политичари су желели да га одвоје од Мађарске и створе независну Банатску републику, која би затим добила европско признање а касније се стопила са мађарском државом. Када је мађарска опозиција на челу са грофом Михаљем Карољијем преузела власт у Будимпешти, стекли су се услови да овај план буде остварен.

\footnotetext{
${ }^{1}$ Arpad Lebl, Neka Narodna veća u Banatu - Novembar 1918, Beograd-Kotor, oktobar, 1967. (Naučni skup „Oktobarska revolucija i narodi Jugoslavije“ povodom 50-godišnjice Velike oktobarske socijalističke revolucije, štampano kao rukopis za učesnike skupa), 1.

2 Љубивоје Церовић, Срби у Румунији, Нови Сад 1991, 181.

${ }^{3}$ Petar Pekić, Povijest oslobođenja Vojvodine, Subotica 1939, 189.

${ }^{4}$ Вид. опширније: Владан Гавриловић, Темишварски сабор и Илирска дворска канцеларија, Нови Сад 2005.
} 
У Темишвару је 31. октобра 1918. године одржан народни збор Мађара и Немаца на коме је истакнуто да као што сваки народ и свака покрајина имају право да одлучују о својој судбини тако и Банат има право да буде независна република. ${ }^{5}$ Речено је и „како су остали делови Мађарске само искориштавали плодни Банат који има све услове за самостални државни живот“б. Тада је образовано и народно веће које је имало сву грађанску и војничку власт у Банату. Истог дана, када је проглашено Мађарско народно веће, социјалдемократи из редова Немаца, у сарадњи са Мађарима, прогласили су Банатску републику. ${ }^{7}$ Поред Немаца и Мађара у Народни савет Банатске републике био је укључен и један број Срба и Румуна како би се показало да ће наводно и мањине моћи да учествују у власти. За грађанског комесара је изабран др Ото Рот (Otto Roth), адвокат у Темишвару, који је у рукама имао сву административну власт. За војног комесара је изабран мађарски пуковник Алберт Барта (Albert Barta), чији је задатак био да сачини грађанску гарду и војску за очување мира и јавног поретка. ${ }^{8}$ Представници Банатске републике успротивили су се томе да српске војне јединице запоседну Банат. ${ }^{9}$ Банатска република, називана у изворима и као Ротова република, обухватала је Тамишку, Торонталску и Крашосеверинску жупанију. У прогласу Републике свим народностима су гарантована једнака грађанска права и слободна употреба матерњег језика у свим школама и јавним управама. Дакле, једноставно је проглашена нова независна држава. Срби и Румуни сигурно нису били за овакво решавање ситуације у Банату. Они су желели уједињење са својим народима и нису били за одвојену државу, „поготово не за тако безначајну републику као што би била Банатска, у којој би побеђени Мађари као мањина водили главну реч““10. Коначно, по свом проглашењу Банатска република је требало да има власт над целим Банатом, али она није успевала владати ни у самом Темишвару. У тим временима никакав ауторитет одозго није могао имати позитивних резултата. ${ }^{11}$ Зато је у Темишвару формирано Српско народно веће. Приликом конституисања Српско народно веће донело је резолуцију, којом је истакнуто право народа у Угарској да се определи да живи у заједници са својим сународницима. Почасни председник постао је епископ темишварски Георгије Летић, председник Светозар Давидов, потпредседник Младен Пилић, а секретар Ђура Терзин. Формирано је и Српско војничко веће на челу са капетаном Етом Ђаконовићем. Сутрадан, 1. новембра 1918. године у виду закључака формирани су

\footnotetext{
${ }^{5}$ P. Pekić, Povijest oslobođenja Vojvodine, 189-190.

${ }^{6}$ Исто, 191.

${ }^{7}$ На ситуацију у Банату утицали су и Румуни. У манифесту упућеном румунском народу, Централно веће Румуна Угарске, 6. новембра 1918. године, захтевало је „потпуну власт управљања на територијама које насељавају Румуни у Трансилванији и Угарској“. Румунски прваци су се позивали на историјске аргументе, полазећи из времена Дакије, па до одредаба Лондонске конвенције, којом су за учешће у рату Румунији савезници обећали читав Банат, све до Тисе, надомак Београда. С тим у вези, отпочела је акција формирања румунских народних већа у читавом Банату. Љ. Церовић, Срби у Румунији, 181.

8 Љубивоје Церовић, Срби у Темишварском Банату на историјском раскрићу 1918-1919. године, Присаједињење Војводине Краљевини Србије 1918 (ур. Милутин Смиљанић), Нови Сад 1993, 113-134.

9 Љ. Церовић, Срби у Румунији, 179.

${ }^{10}$ P. Pekić, Povijest oslobođenja Vojvodine, 190.

${ }^{11}$ Исто, 191.
} 
захтеви Срба у Темишвару и околини. У захтевима је истакнуто да је озбиљно нарушен јавни ред, па уколико се не може одржавати сопственим снагама, потребно је позвати снаге Антанте „да у Банат што пре уђу и ту јавну безбедност пазе“. Требало је успоставити везе са српским народним одборима у околини и шире. На истом скупу, изабран је Егзекутивни одбор као орган извршне власти. Његов састав чинили су: капетан Ета Ђаконовић, мерник Младен Пилић и подофицир Ливије Поповић. Темишварско народно веће успоставило је везе са Народним вијећем СХC у Загребу, Српским народним одбором у Новом Саду, као и одговарајућим телима у Банату, пре свега у Великом Бечкереку, Великој Кикинди и Вршцу. Српско народно веће у Темишвару проширено је на 32 члана. Тако су за Фабрику задужени Илија Белеслијин и Милан Калиновић, за Град Никола Живковић и Ђура Терзин, за Јосифово и Мајуреве Мита Крајован и Милош Недељковић, а за Мехалу Влада Торђански и Љуба Бесуљ. На народном збору у Темишвару, 10. новембра је изражено непоколебљиво опредељење Срба да живе у југословенској држави.

Пошто се немачка војска повукла 14. новембра из Темишвара ка Сегедину, српска војска је под командом коњичког пуковника Ђорђа Ђорђевића сутрадан заузела Темишвар. Српска војска је била дочекана уз овације, са српским заставама, цвећем, певањем српске химне и других родољубљивих песама. Требало је да војску поздрави Михајло Полит Десанчић, који је тада био у Темишвару, ${ }^{12}$ али је од великог узбуђења добио слабији срчани удар. Њега су посетили командант коњичке бригаде пуковник Никола Целовић и коњички пуковник Петар Саватић. „Полит је од радости плакао као дете. Благо мени што сам доживео да овде видим српске официре. Живели соколови моји. “13 Српска коњица је наставила према Араду и заузела линију Арад-Темишвар-Лугош-Карансебеш-Оршава, дакле цео источни и јужни Банат, док су средњи, западни и северни Банат још неколико дана држали Мађари.

У Темишвару се очекивало да ће као и у другим ослобођеним градовима на чело грађанских власти бити постављени Срби, али се то није догодило. ${ }^{14}$ Српска војна команда је 17. новембра појединим јединицама окупационе војске упутила наредбу да се мађарски самоуправни чиновници не мењају са својих положаја, ако „тачно удовоље свим потребама месних команданата српске војске“15. И поред тога, у другим местима су војне власти смениле главне представнике мађарске власти по жељи српског становништва јер су у томе виделе већу гаранцију мира и јавног поретка, па се очекивало да ће се то десити и у Темишвару. Међутим, пуковник Ђорђевић је оставио и даље на власти представнике Банатске републике, иако су се њихови циљеви видно косили са српским интересима у Банату. Др Отон Рот је успео да увери пуковника Ђорђевића у своју приврженост Београду, док је заправо био одани слуга Будумпеште. Када су касније српске власти именовале др Мартина Филипона за великог жупана, пуковник Ђорђевић је и даље на власти држао Рота,

\footnotetext{
12 Дејан Микавица, Михајло Полит Десанчић: вођа српских либерала у Аустро-угарској, Нови Сад 2007, 425.

${ }^{13}$ P. Pekić, Povijest oslobođenja Vojvodine, 204.

${ }^{14}$ У документу видимо да је и средином децембра још увек актуелно питање преузимање власти и администрације у Темишвару.

${ }^{15}$ P. Pekić, Povijest oslobođenja Vojvodine, 204.
} 
који је представљао централну власт у Банату и издавао наредбе о снабдевању српске војске. „Банатом се, као што видимо, управљало из Београда, Новог Сада, Будимпеште и Темишвара.“"16 Таква политичко-административна аномалија се морала што пре окончати. Пуковник Ђорђевић је и даље упорно подржавао представнике Банатске републике и он је морао бити смењен. На његово место је постављен командант Моравске дивизије пуковник Панта Грујић, који је Филипона одмах увео у дужност великог жупана. ${ }^{17}$

Српски народни одбор у Новом Саду, који је почео са деловањем већ 4. новембра 1918. године, предузео је мере за организовање Велике народне скупштине, која ће одлучити о судбини Баната, Бачке и Барање. Овој акцији прикључила су се и народна већа Буњеваца и Шокаца, Словака и Русина. Заједничко свима била је жеља да се отцепе од Угарске и прикључе Србији, а онда и заједничкој држави Краљевини Срба, Хрвата и Словенаца. На конференцији народних представника Срба, Буњеваца и осталих Словена Баната, Бачке и Барање, донета је одлука да се Велика народна скупштина одржи 25. новембра 1918. године у Новом Саду. Усвојен је и упућен Проглас у којем је наглашено: „Дошло је време да Срби, Буњевци и остали Словени у Бачкој, Банату и Барањи одлуче слободно, по својој вољи, којој држави желе да припадну“. Припадници свих словенских нација са навршених двадесет година живота, мушкарци и жене, бирају посланике по општинама, тако да једног бира хиљаду становника. ${ }^{18}$ Изабрани су били угледни људи у средини која их је бирала. Велика народна скупштина Срба, Буњеваца и осталих Словена у Банату, Бачкој и Барањи, одржана је 25. новембра 1918. године у Новом Саду. ${ }^{19}$ Темишвар су представљали Илија Белеслијин, Христофор Свирчевић, Васа Богданов, Слободан Костић и Ђура Терзин. ${ }^{20}$ Уочи Велике народне скупштине међу војвођанским Србима постојале су две супротстављене идеје о начину прикључења Војводине заједничкој држави. С једне стране, Васа Стајић је сматрао да Војводина треба да се уједини са Србијом преко Народнога вијећа у Загребу, а с друге стране је Јаша Томића желео да се Војводина непосредно присаједини Србији, а онда да се у таквом саставу нађе у новој државној заједници. ${ }^{21}$ Велика народна скупштина одлучила је да се Банат, Бачка и Барања отцепе од Угарске, на основама националног самоопредељења, и то у државноправном, политичком и привредном погледу. Истовремено је проглашено прикључење овог подручја Краљевини Србији. Изражена је искрена жеља „да Српска влада, удружена са Народним већем у Загребу учини све да дође до јединствене државе Срба, Хрвата и Словенаца, под вођством краља Петра и његове династије“. Основана је посебна Народна управа за Банат,

\footnotetext{
${ }^{16}$ Исто, 205.

17 Др Рот и др Јакоби су побегли у Мађарску и однели сто милиона круна, што је требало да припадне српској државној благајни. Исто, 205.

${ }_{18}^{18}$ Љ. Церовић, Срби у Румунији, 179.

19 Љубомирка Кркљуш, Војводина у време присаједињења Краљевини Србији 1918. године, Присаједињење Војводине Краљевини Србије 1918 (ур. Милутин Смиљанић), Нови Сад 1993, 22.

${ }^{20}$ Љ. Церовић у својој књизи Срби у Румунији доноси списак посланика поименце са подручја северног Баната, са Темишварског подручја и са подручја Банатске клисуре.

${ }^{21}$ Slobodan Bjelica, Radikali u Vojvodini 1919-1929, Beograd 2004, 14.
} 
Бачку и Барању, чији је највиши извршни орган био Велики народни савет. ${ }^{22}$ Уједињење је остварено 1. децембра 1918. године у Београду. Тада је, у присуству делегације Народног вијећа и представника владе Краљевине Србије, др Анте Павелић Старији прочитао регенту Александру адресу Народног вијећа, истакавши да је у Загребу обнародовано уједињење Државе Словенаца, Хрвата и Срба са Србијом и Црном Гором. Одговорио је регент Александар, истичући да овим чином испуњава владарску дужност, проглашавајући стварање Краљевства Срба, Хрвата и Словенаца. $^{23}$

Претензије на читаво подручје Баната полагала је Румунија. У том смислу донета је одлука Националног скупа у Алба Јулији, 1. децембра 1918. године, о прикључењу Трансилваније, Баната и угарских земаља Краљевини Румунији. На поменути скуп дошли су и делегати са данашњег подручја југословенског Баната. У Декларацији је прокламовано: „Национални скуп свих Румуна из Трансилваније, Баната и угарских земаља, окупљених преко својих овлашћених представника, 1. децембра 1918. године, проглашава уједињење свих Румуна са свих територија на којима живе, са Краљевином Румунијом“. На ту одлуку реаговала је Народна управа за Банат, Бачку и Барању, већ 4. децембра. Са седнице упућен је акт Српској краљевској влади у Београду, у којем је замољена да проследи протестну ноту влади Краљевине Румуније и свим савезничким владама. Ставове Народне управе верификовала је Велика народна скупштина на својој другој седници 27. фебруара 1919. године у Новом Саду. Тражило се да се Банат прикључи Краљевини Срба, Хрвата и Словенаца, пошто је Банат од VI века био средиште свих српских покрета и српске културе. Мађарски историчари су признавали да су српски и словенски елемент аутохтони у Банату, док су остале националности помоћу државних органа колонизоване, с намером да потисну српски елеменат. Још је истакнуто да су Румуни знатно после Срба населили Банат. Закључено је да српски народ има етнографска и историјска права на Банат.

Први светски рат однео је многе људске жртве, и донео је велика разарања широм простора на којем се живели Срби. Прикључење Баната, Бачке и Барање Краљевини Србији и њихово уједињење у Краљевину Срба, Хрвата и Словенаца за српски народ представљало је остваривање вековних тежњи да живи у слободној и заједничкој држави. ${ }^{24}$ После краткотрајног живота у Краљевини Срба, Хрвата и Словенаца, темишварски Срби су се, одлуком Мировне конференције у Паризу нашли у саставу Краљевине Румуније.

У тим сложеним политичким и националним приликама настао је овај Записник седница Српског Народног Одбора темишварског од 13. (26.) децембра 1918. г.

Након подужег и исцрпног саветовања у предмету преузимања администрације и у осталим крајевима Баната, као и у предмету начина извођења и

\footnotetext{
${ }^{22}$ Исто.

${ }^{23}$ Љ. Церовић, Срби у Румунији, 188.

${ }^{24}$ Исто, 175.
} 
времена, када ће се извођење то извести, након саслушања свих овогодишњих информација и преговора донесено буде ово:

Решење:

Српско нар. Веће изриче да ће у намереној акцији (прецртано) ради састанка скупштине Банатскога Већа учествовати онда ако то Српска Народна управа у Новом Саду прелакидно за потребно нађе и о томе ово Веће својим путем и начином извести.

Уједно се изриче да ово Нар. Веће Војној Управи, а генералу Ђорђевићу свагда стоји најуслужније на расположењу ради саветовања о свима наредним саборима нашима.

Иван Прекајски председник

Младен Пилић председник

Илија Белеслијин потпредседник

ХрСвирчевић потпредседник

Ђ. Терзин тајник

Јован Савковић благајник

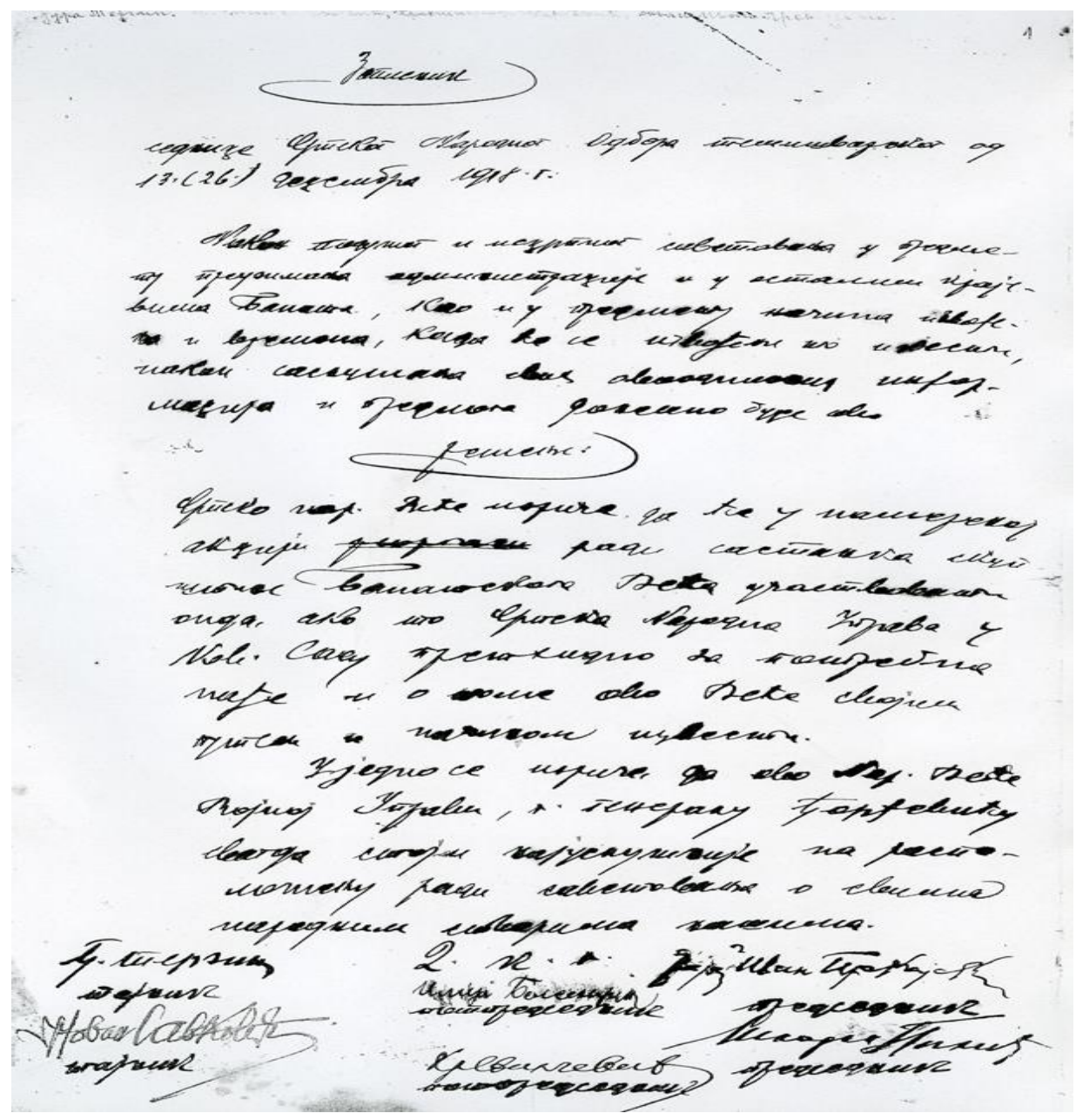


У Зборнику Матице српске - серија друштвених наука из 1955. године објављени су записници са седница темишварског Народног већа. Свеска са записницима коју је приредио академик Богумил Храбак обухвата период од 18/31. октобра до 3/16. новембра 1918. године. Али, период после тог времена није обрађен. Овде презентујемо досад необјављени документ са седнице Народног одбора у Темишвару 13/26. децембра 1918 . године. ${ }^{25}$ Како у предговору свеске пише Б. Храбак, у записницима се види држање Срба у Темишвару новембарских дана 1918. године. У њима има вести из прве руке о везама темишварског Народног већа са сличним одборима у осталом делу Баната и о његовом односу према Народном вијећу у Загребу. Види се, такође, како се отворено постепено мења став централних личности темишварских Срба према Ротовој Банатској републици. ${ }^{26}$ У записнику са краја децембра могу се уочити актуелни проблеми. У документу се поставља проблем преузимања администрације у Темишвару и у осталим крајевима Баната. Што се тиче односа темишварског Народног већа према Народној управи у Новом Саду, можемо уочити да се угледнији темишварски Срби потпуно стављају под њен утицај и да поштују генерала Ђорђевића кога је поставила Народна управа. Српска влада, која званично никада није признала Народну управу, била је замољена да јој призна компетенцију за грађанску административну власт на ослобођеном подручју Баната, Бачке и Барање. О томе су били обавештени команданти српске, француске и енглеске војске. Један од најважнијих задатака који је Народна управа требало да реши, био је да се свим државним установама, сем судских, саопшти текст Резолуције Велике народне скупштине, а да се чиновници позову на полагање заклетве Народној управи. У оваквим сложеним условима основни циљ је био да државне установе непрекинуто наставе да раде. На место распуштених муниципалних већа, одбора и других органа, на подручју Баната, Бачке и Барање формирани су нови варошки сенати, у којима су имали право учешћа сви дотадашњи званичници а довођени су и представници српских народних одбора. Овако проширени варошки сенати имали су да решавају само неодложне текуће послове. На тај начин, престала је функција месних народних одбора, односно већа, који су, како је констатовала Народна управа, учинили „неизмерне услуге у првим данима и чија је заслуга, да су прве тешкоће могле успешно да се преброде“. Све у свему, Народна управа успоставила је врло брзо власт на читавом подручју Баната, Бачке и Барање. У спровођењу одлуке Народне управе о постављању својих органа на чело територијално-административних јединаца на подручје Баната, Бачке и Барање највише отпора било је у Темишвару и Печују. ${ }^{27}$ Илија Белеслијин, члан темишварског Народног већа и члан Великог народног савета БББ, истичући разлоге опирању, 1. децембра 1918. године у писму министру унутрашњих послова истакао je: „С обзиром на специјалне прилике у Темишвару и околини, нашли смо за преко

\footnotetext{
25 Документ је пронађен у Архиву Војводине, Фонд 444. Био је изложен је на изложби „У огледалу времена - српско грађанско друштво на размеђи векова кроз Збирку др Јована Милекића“. Посебно се захваљујем Сањи Гавриловић, једном од аутора изложбе, која ми је скренула пажњу на овај документ.

${ }^{26}$ Богумил Храбак, Записник Темишварског народног већа, Зборника Матице српске - серија друштвених наука св. 10, Нови Сад 1955, 76-88.

27 Љ. Церовић, Срби у Румунији, 189.
} 
потребно да ви као министар унутрашњих послова дођете овамо журно да овдашње прилике проучите и да у ствари увођења у живот Новосадске резолуције учините нарочито расположења да се најјаче несрпске групе милом задобију и у наш табор без потреса уведу“. ${ }^{28} \mathrm{C}$ циљем да размотре могућности за постављање великог жупана за Тамишку и део Крашовске жупаније, у Темишвар долази, 28. јануара 1919. године, председник Народне управе Јоца Лалошевић. Он је преговарао са представницима мађарске власти у присуству генерала Ђорђа Ђорђевића и ранијег министра у влади Краљевине Србије Мике Поповића. У Темишвару Поповић је био задужен за контакте између владе Србије и Народне управе БББ. На преговорима је одлучено да се Мартин Филипон уведе у звање великог жупана. Пошто се у Команди јавио отпор, Народна управа је оштро реаговала, истичући да је једино она одговорна за сву администрацију на територији Баната, Бачке и Барање, те не прихватају одлагање и да се Филипон сместа уведе у звање, до чега ће и доћи 10. фебруара 1919. године. „С тим у вези, у писму министру унутрашњих послова Краљевине СXC, председник Народне управе Јоца Лалошевић је нагласио да је ситуација у Темишвару таква да је захтевала брзо увођење српске управе, која би, преузевши власт, организовала политичку активност ради утицаја на будућу припадност Темишвара и Баната.“ ${ }^{29}$ Одуговлачење није ишло томе у прилог. У основи су лежале супротности између Народне управе и српске команде у Темишвару спрам питања компетенција, тим пре што оне нису биле јасно дефинисане. ${ }^{30}$ Успостављање нове власти, као и функционисање свакодневног живота у ослобођеним крајевима Баната, наилазило је на отпор несловенског становништва, пре свега Мађара и Немаца. Велики проблем је представљало организовање судства. Став Народне управе је био да судство функционише независно од Мађарске, али на основама важећег мађарског законодавства. Према замисли, судски столови у Великом Бечкереку и Великој Кикинди требало је да буду припојени Краљевској табли у Темишвару. Све предлоге одбијала је да прихвати мађарска влада, коју је готово у потпуности подржавало судско особље, које се осећало одговорно само њој. Као одговор на ово, Народна управа је почела са отпуштањем судског особља и државних чиновника, који су одбијали да положе заклетву. Тешко су, међутим, налажене замене, па су део послова почели да преузимају српски војни судови. Сређивање прилика у просвети једнако је задавало бриге Народној управи. С обзиром на то да је велики део наставног особља пребегао у Мађарску, јавила се потреба за обезбеђивање каквих-таквих просветних кадрова, што се у пракси тешко остваривало. Овде се најдрастичније показивало шта је за само неколико деценија учинила мађаризација, када су и иначе у свим областима живота потискивани кадрови националности, пре свега Срби. ${ }^{31}$ Најозбиљнију препреку реализовању одлука Народне управе, поред мађарског и немачког становништва, представљали су органи Банатске републике, који су постали безмало

\footnotetext{
${ }^{28}$ Исто.

${ }^{29}$ Исто.

${ }^{30}$ Исто, 192.

${ }^{31}$ Исто, 193.
} 
паралелна власт Народној управи. Делујући у прво време опрезно и званично независно, када су проценили да је настао повољан тренутак, признали су мађарску власт, по чијим су директивама читаво време деловали. Стрпљиво формирани одбори на терену, читаво време су се припремали за извршење пуча, који би довео до прикључења Баната и читавог запоседнутог подручја у Мађарској. Непобитно утврдивши везе руководства Банатске републике са владом Мађарске на организовању генералног штрајка, неколико дана уочи његовог избијања, 16. фебруара 1919. године, Народна управа је сменила руководство Банатске републике и забранила рад њеним органима. Пошто није усвојена жалба упућена Француској команди у Темишвару, руководство Банатске републике пребегло је у Мађарску, настављајући и даље да ради на штету српске власти у Банату.

\section{Литература:}

Bjelica, Slobodan, Radikali u Vojvodini 1919-1929, Beograd 2004.

Гавриловић, Владан, Темишварски сабор и Илирска дворска канцеларија, Нови Сад 2005.

Кркљуш, Љубомирка, Војводина у време присаједињеља Краљевини Србији 1918. године, Присаједињење Војводине Краљевини Србије 1918 (ур. Милутин Смиљанић), Нови Сад 1993.

Lebl, Arpad, Neka Narodna veća u Banatu - Novembar 1918, Beograd-Kotor, oktobar, 1967. године (Naučni skup „Oktobarska revolucija i narodi Jugoslavije“ povodom 50-godišnjice Velike oktobarske socijalističke revolucije, štampano kao rukopis za učesnike skupa).

Pekić, Petar, Povijest oslobođenja Vojvodine, Subotica 1939.

Храбак, Богумил, Записник Темишварског народног већа, Зборник Матице српске - серија друштвених наука 10, Нови Сад 1955, 76-88.

Церовић, Љубивоје, Срби у Румунији, Нови Сад 1991.

Церовић, Љубивоје, Срби у Темишварском Банату на историјском раскршћу 1918-1919. године, Присаједињење Војводине Краљевини Србије 1918 (ур. Милутин Смиљанић), Нови Сад 1993. 


\title{
CONDITIONS IN TIMIŞOARA \\ AT THE END OF 1918 AND A PREVIOUSLY UNPUBLISHED DOCUMENT OF THE SERBS OF TIMIŞOARA
}

\begin{abstract}
Summary
In the period of creation of the Yugoslav state (November December 1918), and also in the following months, Banat and Timişoara were one of the central places in the politics of Serbia, later the Kingdom of Serbs, Croats and Slovenes. About dynamic development of the events testify many sources, of which a significant number is wellknown in scientific circles. A large contribution to this was given by Bogumil Hrabak who published the record of Timişoara National Council from November 1918. However, this unknown record from December 1918 testifies that many archival sources remain unknown to scientists who have studied the processes in the Banat region at the time of creation of the Kingdom of Serbs, Croats and Slovenes. This fact opens up the possibility of new research and reinterpretation of the achieved results.
\end{abstract}

Keywords: Timişoara, Serbian narodno veće, Serbian narodna uprava (for the Banat, Bačka and Baranja), 1918. 